\title{
PLANT TISSUE CULTURE: A TOOL TO CONSERVE BIODIVERSITY THROUGH RAPID IN VITRO REGENERATION OF DIVERSE PLANT SPECIES
}

\author{
Nirali C. Vora \\ Research Paper \\ For publication in Proceedings of \\ $30^{\text {th }}$ International Conference on Imagi/ Nation: India/ Canada Past, Present and Future, 25-27 $7^{\text {th }}$ March, \\ 2017 \\ Under the Theme: Ecology, Biodiversity and environment
}

\begin{abstract}
Biodiversity is declining with the loss of natural forests across the world. Plant tissue culture is an important biotechnological tool to raise large number of plant species in short span of time. However, commercial tissue culture laboratories are working on raising plantlets important for human consumption only; which mainly include fruit crops, ornamental plants, timber-yielding forest trees and medicinal plants. There is an urgent need of raising all the different plant species rapidly through tissue culture. Through cultivation of these high yielding and disease-free crops in the forests for consumption of all other species of fauna; conservation of biodiversity can be achieved. However, as tissue culture plantlets are costlier than conventionally raised plants, despite of its advantages its utility is limited. To reduce cost of an important fruit crop, banana during its in vitro regeneration, cost-effective alternatives are proposed.
\end{abstract}

\section{Introduction}

Agriculture expansion for cultivation of only economically important crops is one of the major threats for loss of biodiversity. There was a net loss of 129 million ha of forest between 1990 and 2015, about the size of South Africa; while between 2010 and 2015 there was an annual loss of 7.6 million ha and an annual gain of 4.3 million ha per year, resulting in a net annual decrease in forest area of 3.3 million ha ("Global Forest Resources Assessments"). According to FAO, plantation of trees established primarily for timber production should be considered as a forest and cannot replace natural forest; but still records it as a loss of natural forests (Chakrawarthy et al 3). In the period between1990-2015, there was a decline in forest area with increases in agricultural area in different countries ("State of the World's Forests"). In India, $41 \%$ of mammals, $7 \%$ of birds and and $46 \%$ of reptile species are under the threat (Somanathan 2). In Canada, 77\% of the nearly 12,000 species assessed in 2010 are considered "Secure", but 12\% are considered to be "at Risk" or "May be at Risk", while the remaining 11\% are "Sensitive" ("Canada's $5^{\text {th }}$ National Report to the Convention on Biological Diversity"). Out of total of 34 standards for conservation of biodiversity, 94\% make reference to restoration of habitat ("Review of the Biodiversity Requirements of Standards and Certification Schemes: A snapshot of current practices"). In India, $21.34 \%$ of forest cover is left ("Compendium of Environment Statistics 
Towards Excellence: An Indexed, Refereed \& Peer Reviewed Journal of Higher Education / Ms. Nirali Vora / Page132-139

India 2015"); compared to $26 \%$ of forest cover in Canada. Due to loss of natural forests for agriculture, 15-35\% of species will be lost by 2050 (Bellard et al 365). We should focus on food and nutritional requirements of fauna present in a particular area. For this, we should cultivate suitable fruit crops, cereals, pulses, etc in the forests of tropical or temperate region as per the requirement of threatened or vulnerable species of that area. We should also cultivate ornamental plants in forests to attract pollinators and to conserve insects like honeybees, butterflies and birds as these are important to maintain food chain and food web. When a proper food chain is maintained, an ecosystem sustains. With a sustainable ecosystem, goal of conservation of biodiversity can be achieved. Moreover, these pollinators affect $35 \%$ of world's crop production ("Pollinators"). Insect pollination was shown to enhance average crop yield by 18 to $71 \%$ depending on the crop (Bartomeus et al n.p.). Millions of dollars are spent to conserve biodiversity since last two decades across the globe, mainly through restoration of habitat by growing timber-yielding forest tree species.

Plant tissue culture is routinely utilized tool to raise economically important horticultural crops, such as banana, sugarcane, grape, potato, cardamom, ginger, orchid, Aloe, gerbera; and a few timber-yielding forest tree species like teak, eucalyptus and bamboo commercially through rapid in vitro propagation to meet our demand (Department of Biotechnology and Small Farmers' Agri-business Consortium 2). Human population is increasing annually by $1.1 \%$, or 75 million, globally ("The Exponential Growth of the Human Population could Lead to Food Shortages, Global Warming, and Other Issues of Resource Scarcity"). Plant tissue culture technique is useful to raise disease-free, quality and true-to-type planting material round the year, irrespective of season, weather or geographical area. The aggregate production capacity of the recognized 46 large-scale commercial tissue culture units in 2003-2004 in India was 150 million plants/ annum with small units producing additional 20 million ("Department of biotechnology and small farmers' agri-business consortium" 10). In 2015, 94 recognized and certified large-scale tissue culture laboratories were reported in India, each with 0.5-5 million plantlets per annum production capacity ("Recognized Tissue Culture Production Units NCS-TCP"). Banana shares $41 \%$ of the total plant species raised through tissue culture technique and its demand was expected to increase at a high rate of 25-30 \% per annum in India ("Department of biotechnology and small farmers' agri-business consortium" 9). In 2008-09, India ranked first in terms of banana production of the world ("FAOSTAT: ProdSTAT: Crops, Food and Agriculture Organisation"). In 1992, International Development Research Centre (IDRC), Ottawa, Canada and Tata Energy Research Institute (TERI), New Delhi, India co-sponsored a workshop in Delhi on "Mass Propagation of Tree Species Through In vitro Methods" to improve propagation system of woody perennials ("Tissue Culture of Forest tree species: Recent Research in India"). Number of tissue culture industries was declined in India as it was difficult to remain costeffective (Govil and Gupta 65; Prakash 571). Cost of media used for in vitro regeneration constitutes $35 \%$ of a tissue cultured banana plant (Self 185). Gelling agent Agar-Agar used in nutrient media alone contributes $49 \%$ of total cost of media (Self 130). To substitute gelling agent, Agar-Agar in the media, experiments were carried out using more than 20 different alternatives. Similarly, to reduce electricity cost during media sterilization, which is routinely achieved by $121^{\circ} \mathrm{C}$ temperature and 15 psi pressure for $20 \mathrm{~min}$., microwave irradiation was tried to sterilize media and reported useful for the same for the first time. 


\section{Materials and Methods}

Nirali Vora / Page132-139

Suckers of Grand naine variety of banana (Musa paradisiaca Linn.) were collected, washed under running tap-water (30 $\mathrm{min}$ ) and trimmed to remove outer scales. Suckers were pretreated (20 min) with a mixture of $0.05 \%$ of Carbendazim (Bavistin) and $0.1 \%$ of activated charcoal. After thorough washing with distilled water (3 times) the apical shoots were isolated for inoculation (Self and Jasrai 111). The multiplication was carried out in MS medium (Murashige and Skoog 473) containing $3 \mathrm{mg} / \mathrm{l} \mathrm{BA}, 3 \%$ sucrose and $0.8 \%$ Agar-Agar (Cronauer and Krikorian, 321$)$ in culture bottles $(10 X 5 \mathrm{~cm})$. Shoot-clumps with 5 shoots each were transferred to MS medium containing $4 \mathrm{mg} / \mathrm{l} \mathrm{BA}$ during shoot-multiplication cycles. The multiple-shoots were sub-cultured at every four week intervals. In vitro shoot-multiplication was carried out using different substitutes of gelling agents including various matrices, starches, gums and synthetic gelling agents, Gelrite and Agarose. Agar-agar was utilized as the control. Various matrices included Absorbent cotton ( $2 \mathrm{gm} / 50 \mathrm{ml}$ media), polyurethane foam, plastic scrubber, marbles, glass beads, luffa sponge, Jute fibers and coconut-coir; each in liquid MS medium for in vitro shoot-multiplication after washing and sterilizing them properly in an autoclave $\left(121{ }^{\circ} \mathrm{C}\right.$ for $20 \mathrm{~min}$ ). Moreover, corn starch, tapioca starch, potato starch, starch soluble, rice flour, guar gum, carrageenan gum, tragacanth gum, karaya gum and xanthan gum were used as the alternatives of Agar-agar in the medium.

For media sterilization, dosage of microwave irradiation required for complete sterilization was standardized. In vitro shoot-multiplication of banana was carried out on the microwave sterilized media; while the media sterilized in an autoclave was utilized as the control. During this, routinely utilized Agar-Agar $(0.8 \%)$ was used as a gelling agent for both the treatments of media sterilization. The best suited and the most cost-effective substitutes, i.e., Absorbent cotton as a substitute of gelling agent and microwave irradiation as a substitute of autoclave sterilization were used together to find their combined effects on in vitro shoot-multiplication of banana.

All the cultures were kept in the culture room with $25^{\circ} \mathrm{C}$ temperature and $16 \mathrm{~h}$ photoperiod during their growth cycles. For each treatment, 15 replicates were used. Data for each treatment was analyzed after 4 weeks in terms of increase in number of shoots, shoot-length and number of leaves.

\section{Results and Discussion}

Out of various starches, gums and support matrices were used, only certain substitutes showed successful growth and survival of the explants (Table 1). In present study, different substitutes of gelling agent were found to get stabilized at varied $\mathrm{pH}$ range after sterilization in autoclave. The type of gelling agent affects post-autoclave $\mathrm{pH}$, which in turn would affect growth and morphogenesis of different plant species (Owen et al 583). Corn starch as a gelling agent was used for micropropagation of apple, raspberry and pear (Zimmermann et al 207). Guar gum, a high molecular weight hydrocolloidal polysaccharide was reported as a suitable gelling agent for in vitro multiplication of Dendrobium chrysotoxum (Jain and Babbar 292). In present study, however, the medium containing Guar gum was found to procure stickiness after its sterilization, besides losing gelling strength to some extent. Correspondingly, liquefied gel from Guar gum was earlier reported to be formed by dropping the $\mathrm{pH}$ below 7 and by heating (Sarin and Khandelwal 55). Both Tragacanth gum (derived from Astragalus gummifera) and Karaya gum (derived from Sterculia urens) were incorporated here for tissue culture purpose for the first 
Towards Excellence: An Indexed, Refereed \& Peer Reviewed Journal of Higher Education / Ms. Nirali Vora / Page132-139

time. However, these are edible and commonly used as stabilizers in foods, cosmetics, and pharmaceutical products. Both of them showed gel formation at $3 \%$, when used in the coagulated form only. Gelling capacity, stability and strength of tragacanth gum was shown to vary with $\mathrm{pH}$ of media (Yokoyama et al 141). To substitute Agar-Agar, saw-dust, Tapioca starch and Bacto Agar were tried for in vitro micro shoot production of potato (Getrudis and Wattimena 447). Similarly, Cassava starch was used as a substitute of gelling agent, Agar-Agar for in vitro nodal culture of Uapaca kirkiana and Faidherbia albida (Maliro and Lameck 244) and for in vitro micro-propagation of potato (Kuria et al 301).

Table 1: Effect of substitutes of gelling agent on in vitro shoot-multiplication of banana *

\begin{tabular}{|l|l|l|l|}
\hline Gelling Agent & No. of Shoots & Length of Shoot $(\mathbf{c m})$ & No. of Leaves \\
\hline Agar-agar (Control) & $3.6 \pm 0.67$ & $2.20 \pm 0.64$ & $1.8 \pm 0.58$ \\
\hline Agarose & $3.2 \pm 1.21$ & $0.54 \pm 0.12$ & $0.8 \pm 0.37$ \\
\hline Gelrite & $4.6 \pm 2.23$ & $1.50 \pm 0.15$ & $2.4 \pm 0.74$ \\
\hline Tragacanth gum & $4.0 \pm 1.04$ & $0.54 \pm 0.25$ & $0.6 \pm 0.59$ \\
\hline Karaya gum & $3.0 \pm 0.31$ & $0.40 \pm 0.24$ & $0.6 \pm 0.59$ \\
\hline Guar-gum & $1.2 \pm 0.79$ & $1.00 \pm 0.44$ & $1.0 \pm 0.54$ \\
\hline Corn starch & $1.9 \pm 0.40$ & $0.58 \pm 0.17$ & $1.2 \pm 0.48$ \\
\hline Cotton & $4.2 \pm 0.37$ & $0.76 \pm 0.26$ & $1.0 \pm 0.44$ \\
\hline Plastic Scrubber & $3.6 \pm 0.67$ & $1.40 \pm 0.49$ & $1.2 \pm 0.48$ \\
\hline Polystyrene foam & $3.7 \pm 1.02$ & $2.30 \pm 0.25$ & $2.0 \pm 0.31$ \\
\hline Marbles & $4.0 \pm 0.87$ & $2.50 \pm 0.23$ & $1.8 \pm 0.78$ \\
\hline Glass beads & $2.7 \pm 0.63$ & $1.70 \pm 0.25$ & $1.4 \pm 0.48$ \\
\hline Stones & $3.9 \pm 0.79$ & $1.45 \pm 0.29$ & $1.1 \pm 0.34$ \\
\hline Blotting paper layers & $3.2 \pm 1.52$ & $0.10 \pm 0.09$ & $0.0 \pm 0.0$ \\
\hline Luffa Sponge & $0.5 \pm 0.49$ & $1.25 \pm 1.13$ & $1.0 \pm 0.0$ \\
\hline Coir & $2.66 \pm 0.32$ & $0.50 \pm 0.49$ & $1.6 \pm 0.66$ \\
\hline Hemp & $1.33 \pm 0.42$ & $1.25 \pm 0.44$ & $1.0 \pm 0.0$ \\
\hline
\end{tabular}

Table 2: Effect of microwave sterilized media on in vitro shoot-multiplication of banana *

\begin{tabular}{|l|l|l|}
\hline Growth Parameters & Sterilization in Autoclave & Sterilization in Microwave \\
\hline No. of Shoots & $1.00 \pm 0.33$ & $1.90 \pm 0.68$ \\
\hline Length of Shoot $(\mathbf{c m})$ & $0.55 \pm 0.17$ & $0.55 \pm 0.17$ \\
\hline No. of Leaves & $0.80 \pm 0.25$ & $1.30 \pm 0.36$ \\
\hline
\end{tabular}

Table 3: Combined effects of the best suited and cost reducing substitutes on in vitro shootmultiplication of banana * 
Towards Excellence: An Indexed, Refereed \& Peer Reviewed Journal of Higher Education / Ms. Nirali Vora / Page132-139

\begin{tabular}{|l|l|l|l|}
\hline $\begin{array}{c}\text { Combinations of } \\
\text { treatments }\end{array}$ & No. of shoots & Shoot length $(\mathbf{c m})$ & No. of leaf \\
\hline Cotton, Autoclave & $3.3 \pm 0.87$ & $0.66 \pm 0.16$ & $2.00 \pm 0.57$ \\
\hline Cotton, Microwave & $1.00 \pm 1.0$ & $1.25 \pm 1.24$ & $0.50 \pm 0.49$ \\
\hline
\end{tabular}

* Data represent Mean \pm SE of 15 replicates recorded after four weeks

The best suitable alternative of gelling agent for in vitro shoot-multiplication of banana was found to be Absorbent cotton (Fig. 1B) showing high rate of multiplication over control (Fig. 1A). With Absorbent cotton, almost $70 \%$ reduction in cost/ liter media could be achieved over control, Agar-Agar (Self 131). In other matrices used in liquid media, other than cotton, like glass beads, coir, marbles, luffa sponge, hemp, plastic scrubber, polystyrene foam; hyperhydricity of shoots was found with lower rates of multiplication (Table 1).

Microwave sterilized media was successfully achieved using 900W/ $200 \mathrm{ml}$ of media for $4 \mathrm{~min}$ and showed higher rate of shoot-multiplication than the conventional method of media sterilization in autoclave (Table 2). Autoclave sterilization causes hydrolysis of sugars (Eliezer and Roger 291). However, when cotton as a substitute of gelling agent was used with microwave sterilization treatment (Fig. 1C); decline was observed in the rate of in vitro shoot multiplication; compared to the same substitute sterilized in autoclave (Table 3). Structurally, cotton is made up of cellulose, which is insoluble in water. It is a very strong substance because the straight-chain molecules of hydrogen, bonds with one another; forming a pseudocrystalline structure. The strength of cotton was reported to decrease by $10 \%$ after 5 min of microwave exposure (Reagan et al 186).
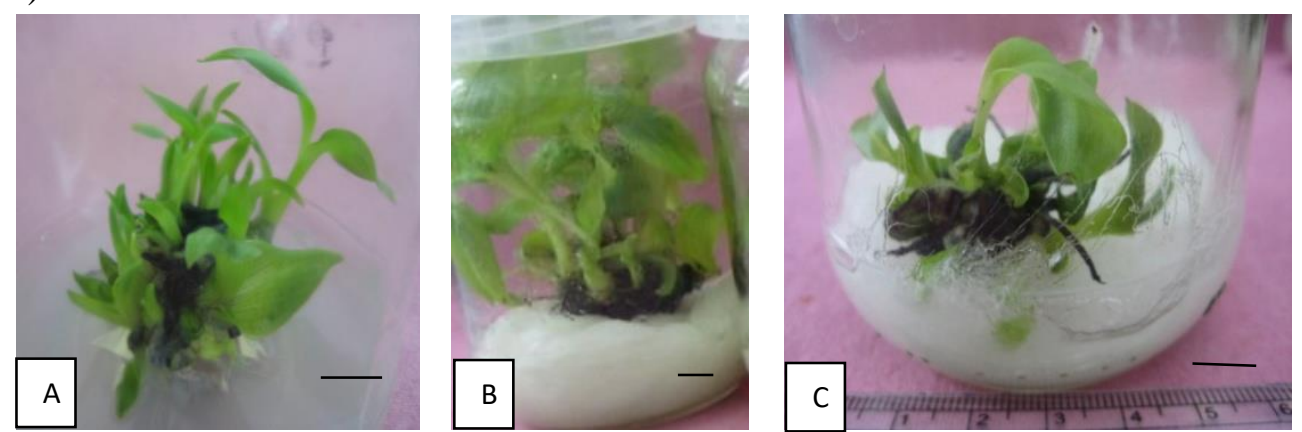

Fig. 1. Effects of cost reducing substitutes on in vitro shoot-multiplication of banana A. Control (AgarAgar), B. Absorbent Cotton with Autoclave sterilization, C. Absorbent cotton with Microwave sterilization (Horizontal bar $=1 \mathrm{~cm}$ ).

In addition to this, cost reducing alternatives for each of the different stages of the protocol for micropropagation of banana var. Grand naine were reported (Self n.p.; Self and Jasrai 9). Moreover, efficient and cost-effective protocols for micropropagation of Verbenaceae members of Gujarat were compared (Self et al 76); which included important tree species and medicinal plants for rapid true-to-type propagation for conservation of biodiversity.

\section{Conclusion}

To improve feasibility of tissue cultured crops, cost-effective production is important, but without sacrificing quality and yield. Once cost-effective large scale in vitro regeneration can be achieved through established protocols of different crops, tissue cultured plants can be cultivated in the forests also; to fulfill food and nutritional requirements of diverse species under the threat. 
For cost-effective in vitro regeneration of banana, Absorbent cotton as a substitute of costly gelling agents should be used with autoclave sterilized media. If, microwave irradiation is to be used for media sterilization, Agar-Agar as a gelling agent should be used; instead of Absorbent cotton. Otherwise, cotton fibers would not be able to absorb media properly, reducing rate of in vitro regeneration.

Moreover, it is here by proposed that to conserve biodiversity, conventional ways of monoculture and scenario of growing the same tree species for reforestation should be changed. Dominant species in an area suggests that it is a final stage of ecological succession; where no other species could survive. Biodiversity cannot be maintained through the plantation of the same woody perennial grown to meet our demand of timber in the forest. Despite of that, plantation of diverse plant species in the forests, carried out strictly for the consumption of fauna only; in combination of pulses, vegetables, fruits, cereals and ornamentals with honey glands would help diverse species of fauna to survive in each of different flowering and fruiting seasons. Otherwise, a particular dominant species in an area can provide food and nourishment only during its particular flowering or fruiting season. In addition to this, instead of offering mono-diet; diverse plant species can provide different vitamins, amino acids, minerals for their proper growth and development. If specific requirement of a balanced diet for each of the threatened species is fulfilled round the year, apart from just paying attention to restoration of habitat; goal of conservation of biodiversity would be achieved successfully. The forest cover with timber-yielding tree species can provide shelter or habitat and can purify air; but offers no food for the herbivores, birds or pollinator insects. Thus, even though there is a forest cover; biodiversity is declining due to disturbed food chain and ecosystem and as a result carnivores or top consumers also come under the threat. In agro-forestry, mixed crop is cultivated, but that too to meet our demand of food, fodder, fuel and timber; and not for fauna. If required, new provisions and amendments in forest conservation act should be introduced to fulfill nutritional requirement of each of the fauna species. Orchards should be prepared organically and protected by forest departments under the supervision of forest conservators to meet nutritional requirement of the threaten species in each seasonal variations. New horizons to study dietetics fauna or studies on calorific requirement of fauna should be opened up. Thus, taking care of nutritional requirement for any species should also be included as one of the standards to conserve biodiversity; in addition to only considering restoration of habitat by different agencies working for conservation of biodiversity, ecology and environment across the globe. 
Towards Excellence: An Indexed, Refereed \& Peer Reviewed Journal of Higher Education / Ms.

Nirali Vora / Page132-139

Works cited

Bartomeus I, Potts SG, Steffan-Dewenter I, Vaissiere BE, Woyciechowski M, Krewenka KM, Tscheulin T, Roberts SPM, Szentgyorgyi H, Westphal C and Bommarco R "Contribution of Insect Pollinators to Crop Yield and Quality Varies with Agricultural Intensification.” Ed. Anna Traveset. PeerJ 2 (2014): e328. PMC. Web. 22 Mar. 2017.

Bellard C, Bertelsmeier C, Leadley P, Thuiller W, and Courchamp F "Impacts of Climate Change on the Future of Biodiversity" Ecol. lett. 15 (2012): 365-377. Web. 20 Mar. 2017.

"Canada's $5^{\text {th }}$ National Report to the Convention on Biological Diversity". Canadian Wildlife Service, Envirnment, Canada. n.p., n.d. Web. 21 March 2017.

Chakravarty S, Ghosh SK, Suresh SP, Dey AN and Shukla G "Deforestation: Causes, Effects and Control Strategies." Global Perspectives on Sustainable Forest Management, Ed. Okia Clement Akais: InTech Publishers, 2012. Web. 20 March 2017.

"Compendium of Environment Statistics India 2015". Government of India. Minsitry of Statistics \& Programme Implementation, Social Statistics Division, New Delhi (2015) n.p. Web. 11 Apr. 2017.

Cronauer SS, and Krikorian AD "Multiplication of Musa from Excised Stem tips." Annals of Botany 53.3 (1984): 321-28. Web. 20 Feb. 2009.

“Department of Biotechnology and Small farmers' Agri-business Consortium". Summary Report on Market Survey on Tissue-cultured Plants. Biotech Consortium India Ltd. India. Department of Biotechnology, Govt. of India. India, 2005. <http://dbtmicropropagation.nic.in/surveytcp.pdf>. Web. 20 Jan. 2009.

Eliezer Z and Roger W "Steriospecificity of the Glucose Carrier in Sugar beet Suspension Cells." Journal of Plant Physiology. 78 (1985): 291-295. Web. 18 Jan. 2011.

"The Exponential Growth of the Human Population could Lead to Food Shortages, Global Warming, and Other Issues of Resource Scarcity" Human Population Growth. Boundless Biology, 2016. $<$ Boundless.com> n.p., n.d. Web. 20 Mar. 2017

"FAOSTAT: ProdSTAT: Crops, Food and Agriculture Organisation" FAOSTAT. Food and Agriculture Organization of the United Nations. UN, 2010. n.p., n.d. <http://faostat.fao.org/site/567/DesktopDefault.aspx?PageID=567>. Web. 12 Mar. 2010.

Getrudis DJM, and Wattimena CA. "The effect of Agar Substitution on Micro Shoots for the Production of two Potato Cultivars (Solanum Tuberosum L.)." Acta Horticulturae 369 (1994): 447-50. Web. 15 Feb. 2011.

“Global Forest Resources Assessments” Food and Agriculture Organization of the United Nations, Rome, 2016. n.p. Web. 20 Mar. 2017.

Govil S and Gupta SC. "Commercialization of Plant Tissue Culture in India." Plant Cell, Tissue and Organ Culture 51 (1997): 65-73. Web. 20 Mar. 2017.

Jain R and Babbar SB "Guar gum and Isubgol as Cost-effective Alternative Gelling Agents for In vitro Multiplication of an Orchid, Dendrobium chrysotoxum." Current Science 88 (2005): 292-295. Web. 10 Mar. 2010.

Kuria P, Demo P, Nyende AB and Kahangi EM "Cassava Starch as an Alternative Cheap Gelling Agent for In vitro Micro-propagation of Potato (Solanum tuberosum L.)." African Journal of Biotechnology 7 (2008): 301-307. Web. 9 Feb. 2009.

Maliro MFA and Lameck G "Potential of Cassava Flour as a Gelling Agent in Media for Plant Tissue Cultures.” African Journal of Biotechnoloty 3 (2004): 244-247. Web. 9 Feb. 2009. 
Towards Excellence: An Indexed, Refereed \& Peer Reviewed Journal of Higher Education / Ms. Nirali Vora / Page132-139

Murashige T and Skoog F "A Revised Medium for Rapid Growth and Bioassays with Tobacco Tissue Culture.” Physiologia Plantarum 15 (1962): 473-497. Web. 11 Sept. 2007.

Owen HR, Wengerd D and Miller AR "Culture Medium pH is Influenced by Basal Medium, Carbohydrate Source, Gelling Agent, Activated Charcoal and Medium Storage Method." Plant Cell Reports 10 (1991): 583-586. Web 10 Mar. 2010.

Prakash J. "Plant Tissue Culture: Concept to Commercialisation in South-east Asia." International Symposium on In Vitro Culture and Horticultural Breeding. Acta Horticulturae 560 (2001): 571574. 〈www.actahort.org/books/560/560_117.htm>. n.p. Web. 25 Mar. 2010.

"Pollinators" Biodiversity- for a world without hunger. Food and Agriculture Organization of the United Nations. n.p. Web. 21 Mar. 2017.

Reagan BM, Rollow AM and Urban JU "Microwave Sterilization on Polyester and Cotton." Textile Research Journal 52 (1982): 186-192. Web. 20 Jan. 2010.

"Recognized Tissue Culture Production Units NCS-TCP" National Certification System of Tissue cultured plants. Department of Biotechnology (DBT), Govt. of India, India. n.d., n.p. $<w w w . d b t n c s t c p$.nic.in>. Web. 20 Mar. 2017.

"Review of the Biodiversity Requirements of Standards and Certification Schemes: A snapshot of current practices" Secretariat of the Convention on Biological Diversity, Montréal, Canada. 2011. Web. 20 Mar. 2017.

Sarin R and Khandelwal S “A Non Ionic Water Soluble Gum from Cymopsis tetragonoloba Linn. In vivo and In vitro Culture." Journal of Indian Botanical Society 87 (2008): 53-56. Web. 9 Feb. 2009.

Self “Cost Reducing Alternatives of Micropropagation of Banana.” Ph.D. Thesis, Gujarat University, Ahmedabad. (2011). Print.

Self and Jasrai YT "Effect of Various Carbon Sources on In vitro Shoot Multiplication of Banana." Phytomorphology 61 (2011): 111-116. Print.

Self and Jasrai YT "Natural and Low-cost Substitutes of Synthetic PGR for Micropropagation of Banana." CIBTech Journal of Biotechnology 2.1 (2012): 9-13. Web. 20 Dec. 2012.

Self, Kannan RV and Jasrai YT "Micropropagation of Important Verbenaceae Members of Gujarat." Research Journal of Biotechnology 4.3 (2009): 76-79.

Somanathan E. Biodiversity in India. Prepared for the Oxford Companion to Economics in India. Planning unit. Indian Statistical Institute, Delhi. n.d. Web. 20 Mar 2017.

"State of the World's Forests" Forest and Agriculture: Land use challenges and opportunities. $2^{\text {nd }}$ ed. Food and Agriculture Organization of the United Nations. Rome, 2016. pp. 1-54. Web. 20 Mar. 2016.

"Tissue Culture of Forest tree species: Recent Research in India". Proceedings of the National Workshop on 'Mass Propagation of Tree species through In Vitro Methods', Mar. 16-17; 1992. Eds. Dhawan V, Ganapathy PM and Khurana DK. (1993) pp. 1-116. Web. 19 Mar. 2017.

Yokoyama A, Srinivasan KR and Fogler HS "Stabilization Mechanism of Colloidal Suspension by Gum Tragacanth: The Influence of $\mathrm{pH}$ on Stability." Journal of Colloid and Interface Science 126 (1988): 141-149. Web. 12 Feb. 2010.

Zimmerman RH, Bhardwaj SV and Fordham IM "Use of Starch-gelled Medium for Tissue Culture of Some Fruit Crops.” Plant Cell, Tissue and Organ Culture 43 (1995): 207-213. Web. 11 March 2010.

Nirali C. Vora

Gujarat Arts and Science College, Gujarat University, Ahmedabad

July, 2017. VOL.9. ISSUE NO. 2

www.ascgujarat.org

Page | 139 